\title{
EVALUASI APLIKASI SISTEM INFORMASI PENERIMAAN ONLINE MENGGUNAKAN INFORMATION SYSTEMS SUCCESS MODEL (STUDI KASUS: OTORITAS JASA KEUANGAN)
}

\author{
Achmad Ramadhani ${ }^{1)}$, Edwin Riksakomara, S.Kom, MT ${ }^{2)}$ \\ Jurusan Sistem Informasi, Fakultas Teknologi Informasi, Institut Teknologi Sepuluh Nopember (ITS) \\ J1. Arief Rahman Hakim, Surabaya 60111 Indonesia \\ e-mail: achmad.ramadhani11@gmail.com ${ }^{1)}$,erk@is.its.ac.id ${ }^{2)}$
}

\begin{abstract}
ABSTRAK
Otoritas Jasa Keuangan merupakan suatu lembaga yang berfungsi untuk menyelenggarakan sistem pengaturan dan pengawasan yan terintegrasi terhadap keseluruhan kegiatan di dalam sektor jasa keuangan. Lembaga ini menyediakan sistem yang bernama SIPO (Sistem Informasi Penerimaan Online) yang dapat digunakan sebagai alat bantu bagi OJK untuk mengelola pembayaran pungutan OJK dengan lebih cepat dan mudah secara online. Pada dasarnya sistem ini digunakan untuk memudahkan bagi OJK, namun demikian, OJK ingin mengetahui apakah SIPO (Sistem Informasi Penerimaan Online) berhasil memberikan informasi yang diberikan kepada pengguna implementasinya.Oleh karena itu perlu adanya penilaian kualitas sistem informasi penerimaan online (SIPO) di Otoritas Jasa Keuangan (OJK).

Dengan adanya permasalahan ini maka akan dilakukan evaluasi aplikasi tersebut dengan menggunakan Information Systems Success Model dan untuk perhitungan akan menggunakan Structural Equation Model (SEM) yang nantinya akan dilakukan survei pada internal OJK yang menggunakan sistem ini dan hasil dari survei data akan dihitung menggunakan LISREL.

Hasil dari tugas akhir ini adalah diharapkan dapat membantu Otoritas Jasa Keuangan dalam hal mengetahui apakah SIPO berhasil memberikan informasi yang diberikan kepada pengguna implementasinya yang telah diterapkan serta memberikan masukan indikator yang bernilai jelek menurut pengguna dan beberapa contoh perbaikan yang bisa dilakukan.
\end{abstract}

Kata Kunci : Otoritas Jasa Keuangan, Sistem Informasi Penerimaan Online, Information Systems Success Model, Structural Equation Modeling, LISREL

\section{PENDAhULUAN}

Otoritas Jasa Keuangan menyediakan sebuah sistem informasi secara online yaitu sistem informasi penerimaan online (SIPO) yang dapat digunakan oleh internal OJK. Tujuan dari penerapan sistem ini adalah untuk memudahkan melakukan pembayaran dan melakukan pemeriksaan apakah perusahaannya sudah melakukan pembayaran atau belum atau sudah terjadi jatuh tempo. Selain itu untuk internal OJK yang berperan sebagai pengawas juga dapat melakukan pemeriksaan yang bertujuan mengawasi wajib bayar. Namun masih belum diketahui apakah sistem ini sudah sesuai dengan yang diharapkan dan layananan yang diberikan dapat memudahkan pengguna. Oleh sebab itu akan dilakukan penghitungan dengan ISSM, nantinya akan diadakan survey pada perusahaan dan kemudian akan dilakukan pengukuran terhadap hasil survey.

Dengan menggunakan model ISSM dapat diketahui faktor-faktor mempengaruhi kesusksesan Sistem Informasi Penerimaan Online. Analisis tersebut diperkuat dengan perhitungan pendekatan Structural Equation Modeling (SEM). SEM dipilih karena memiliki fleksibilitas lebih tinggi untuk menghubungkan antara teori dan data. Selain itu dalam ilmu-ilmu sosial banyak variable yang bersifat laten, seperti motivasi seseorang, komitmen, kesetiaan pelanggan, dan lainnya yang tida bisa diukur dengan metode statistic biasa dan harus menggunakan SEM.
Penelitian ini bertujuan untuk mendapatkan faktor apa saya yang dapat digunakan untuk mengevaluasi penilaian sistem tentang kesuksesan sistem informasi penerimaan online. Selain itu juga untuk membuat analisis mengenai kesuksesan sistem informasi penerimaan online dengan menggunakan model Information Systems Success Model (ISSM). Tujuan terakhir diharapkan dapat memberikan rekomendasi yang tepat untuk pengembangan Aplikasi berbasis website OJK sebagai $e$-Goverment yang lebih baik berdasarkan faktor-faktor krisis yang dihasilkan.

\section{TINJAUAN PUSTAKA}

\subsection{Sistem Informasi Penerimaan Online (SIPO)}

SIPO (Sistem Informasi Penerimaan Online) adalah sistem informasi berbasis online yang disediakan sebagai alat bantu bagi OJK untuk mengelola pungutan OJK dengan lebih cepat dan mudah.

Fungsi yang tersedia dalam SIPO termasuk dalam bentuk penyediaan informasi pungutan OJK yang masih harus dibayarkan, memasukkan dasar pengenaan dan pengelolaan pembayaran Biaya Tahunan, Denda, dan Sanksi, dan Catatan Masa Transisi. Kewajiban pembayaran pungutan sesuai Peraturan Pemerintah Nomor 11 Tahun 2014 tentang Pungutan oleh Otoritas Jasa Keuangan telah berlaku sejak 12 Februari 2014.

Saat ini SIPO belum dapat digunakan untuk pembayaran pungutan karena masih memerlukan perangkat regulasi yang akan segera diterbitkan oleh OJK. 
Biaya perizinan, persetujuan, pendaftaran, pengesahan, dan penelaahan atas rencana aksi korporasi yang telah disampaikan kepada OJK sejak 12 Februari 2014 sampai dengan diterbitkannya regulasi yang menjadi dasar operasionalisasi SIPO akan ditagih oleh OJK segera setelah diterbitkannya regulasi dimaksud.

Permohonan perizinan, persetujuan, pendaftaran, pengesahan, dan penelaahan aksi korporasi yang disampaikan kepada OJK sebelum diterbitkannya regulasi yang menjadi dasar operasionalisasi SIPO tetap akan diproses oleh OJK, meskipun biaya atas permohonan dimaksud belum dibayar.

Berikut merupakan proses bisnis yang ada pada saat memulai menggunakan Sistem Informasi Penerimaan Online (SIPO)

\subsubsection{Proses Registrasi}

Proses ini berisi langkah - langkah wajib bayar dalam mendaftarkan institusinya pada sistem. Pertama kali wajib bayar melakukan registrasi melalui Sistem Informasi Penerimaan Online (SIPO) dan mencetak surat setoran. Setelah itu wajib bayar melakukan pembayaran biaya registrasi ke rekening OJK. Setelah pembayaran sudah dilakukan oleh wajib bayar makan akan disampaikan secara elektronik ke SIPO. Setelah berhasil melakukan registrasi, wajib bayar dapat melihat status registrasi dan history transaksi melalui SIPO.

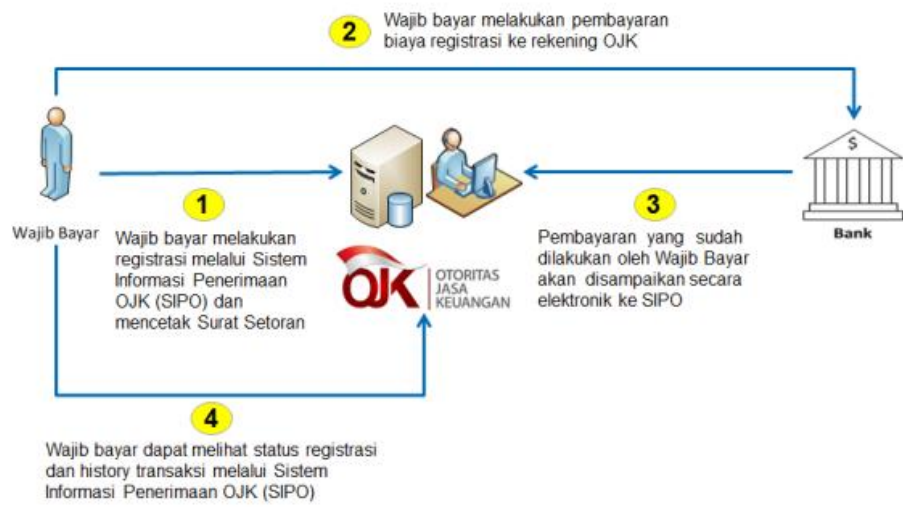

\section{Gambar 1 Proses Registrasi}

\subsubsection{Alur Proses Aksi Korporasi}

Menu Aksi Korporasi digunakan untuk pihak yang tidak melakukan kegiatan di sektor jasa keuangan yang akan melakukan aksi korporasi terhadap perusahaan Wajib Bayar tanpa melakukan registrasi pada SIPO. Pertama kali yang dilakukan adalah wajib bayar melakukan transaksi Aksi Korporasi melalui Sistem Informasi Penerimaan Online (SIPO) dan mencetak Surat Setoran. Setelah itu Wajib bayar melakukan pembayaran biaya aksi korporasi ke rekening OJK. Pembayaran yang sudah dilakukan oleh Wajib Bayar akan disampiakan secara elektornik ke SIPO. Wajib bayar dapat melihat riwayat transaksi melalui Sistem Informasi Penerimaan Online (SIPO).

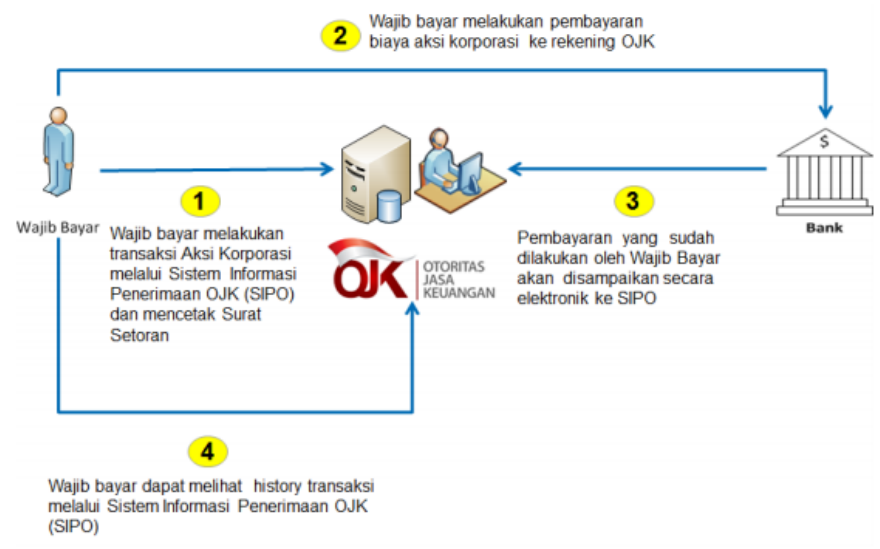

Gambar 2 Alur Proses Aksi Korporasi

\subsubsection{Pembayaran Pungutan}

Proses ini menunjukkan tahapan - tahapan dalam melakukan pembayaran punggutan oleh Wajib Bayar. Langkah pertama yang dilakukan adalah Wajib Bayar menentukan item pungutan OJK yang akan dibayar dan mencetak Surat Setoran melalui SIPO. Berikutnya Wajib Bayar melakukan pembayaran pungutan ke rekening OJK yang ditunjuk dengan mencantumkan No. Referensi Setoran. Setelah melakukan pembayaran oleh Wajib Bayar akan disampiakan secara elektronik ke SIPO. Wajib bayar dapat melihat status pembayaran melalui Sistem Informasi Penerimaan Online (SIPO).

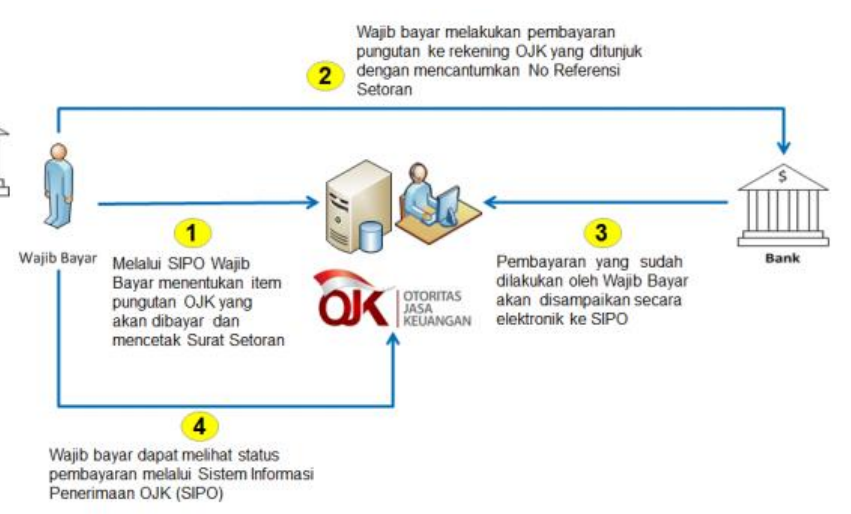

Gambar 3 Pembayaran Pungutan

\subsection{Evaluasi Model}

Model yang digunakan pada penelitian kali ini berdasarkan pada DeLone dan McLean yang berdasarkan jurnal acuan, penelitian ini mengusulkan model multidimensional untuk menilai keberhasilan sistem informasi penerimaan online (SIPO) pada OJK. Model tersebut menunjukan bahwa information quality, system quality, service quality, intention to use, user satisfaction, dan perceived net benefit menjadi variabel-variabel keberhasilan sistem informasi penerimaan online. Gambar $\mathbf{4}$ adalah model dan hipotesa yang digunakan dalam penelitian. 


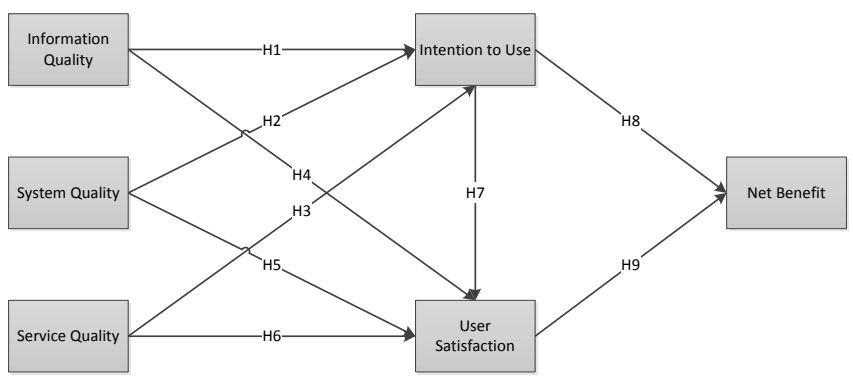

Gambar 4 Hipotesis

- H1 : Information Quality memiliki dampak terhadap Intention to Use.

- H2 : System Quality memiliki dampak terhadap Intention to Use.

- H3 : Service Quality memiliki dampak terhadap Intention to Use.

- H4 : Information Quality memiliki dampak terhadap User Satisfication.

- H5 : System Quality memiliki dampak terhadap User Satisfication.

- H6 : Service Quality memiliki dampak terhadap User Satisfication.

- H7 : Intention to Use memiliki dampak terhadap User Satisfication.

- H8 : Intention to Use memiliki dampak terhadap Net Benefit.

- H9 : User Satisfication akan berpengaruh terhadap Net Benefit.

\subsection{Structural Equation Model (SEM)}

Structural Equation Model (SEM) adalah teknik analisis statistika yang mengkombinasikan beberapa aspek yang terdapat pada analisis jalur dan analisis faktor konfirmatori untuk mengestimasi beberapa persamaan secara simultan. Model persamaan struktural merupakan generasi kedua teknik analisis multivariat yang memungkinkan untuk menguji hubungan antara variabel yang kompleks untuk memperoleh gambaran menyeluruh mengenai keseluruhan model.

\section{IMPLEMENTASI}

\subsection{Penyebaran Kuisoner}

Kuisoner disebar melalui Form Google kepada karyawan $O J K$ seluruh Jawa Timur yang menggunakan SIPO. Data yang digunakan sebagai bahan tugas akhir ini berasal dari responden yang menggunakan SIPO pada $O J K$ seluruh Jawa Timur. Terdapat 120 reponden yang mengisi kuisoner dari seluruh $O J K$ di Jawa Timur.

\subsection{Pengolahan Data}

Data dari hasil kuisoner dimasukkan ke Microsoft Excel. Jawaban dari butir kuisoner diubah menjadi nilai sesuai dengan skala linkert. File .xls dari Microsoft Excel digunakan sebagai data inputan pada Software Lisrel.

\subsection{Diagram Jalur}

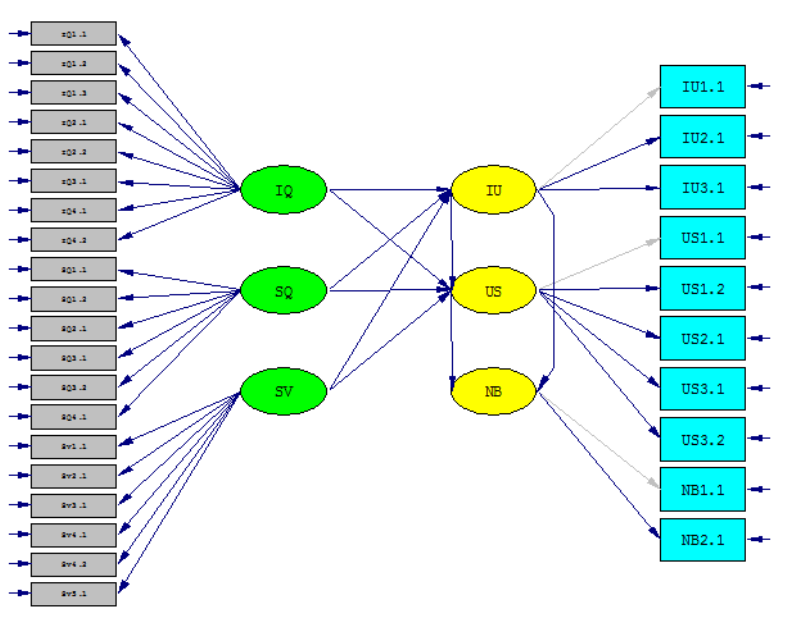

Gambar 5 Diagram Jalur

Berikut ini adalah koversi diagram jalur ke persamaan matematika dari setiap variabel yang digunakan dalam pengerjaan tugas akhir.

1. Untuk variabel IQ

$$
\begin{aligned}
& \text { IQ1.1 }=\lambda_{x 11} \xi 1+\delta 1 \\
& \text { IQ1.2 }=\lambda_{x 12} \xi 1+\delta 2 \\
& \text { IQ1.3 }=\lambda_{x 13} \xi 1+\delta 3 \\
& \text { IQ2.1 }=\lambda_{x 14} \xi 1+\delta 4 \\
& \text { IQ2.2 }=\lambda_{x 15} \xi 1+\delta 5 \\
& \text { IQ3.1 }=\lambda_{x 16} \xi 1+\delta 6 \\
& \text { IQ4.1 }=\lambda_{x 17} \xi 1+\delta 7 \\
& \text { IQ4.2 }=\lambda_{\times 18} \xi 1+\delta 8
\end{aligned}
$$

Maksud dari persamaan ini adalah IQ1.1 memberikan pengaruh sebesar $\lambda_{x 11}$ terhadap variabel laten IQ ditambah dengan variabel error $\delta 1$.

2. Untuk variabel $S Q$

$$
\begin{aligned}
& \mathrm{SQ} 1.1=\lambda_{\times 19} \xi 2+\delta 9 \\
& \mathrm{SQ} 1.2=\lambda_{\mathrm{x} 20} \xi 2+\delta 10 \\
& \mathrm{SQ2.1}=\lambda_{\mathrm{x} 21} \xi 2+\delta 11 \\
& \mathrm{SQ3.1}=\lambda_{\mathrm{x} 22} \xi 2+\delta 12 \\
& \mathrm{SQ3.2}=\lambda_{\mathrm{x} 23} \xi 2+\delta 13 \\
& \mathrm{SQ} 4.1=\lambda_{\mathrm{x} 24} \xi 2+\delta 14
\end{aligned}
$$

Maksud dari persamaan ini adalah SQ1.1 memberikan pengaruh sebesar $\lambda_{x 19}$ terhadap variabel laten SQ ditambah dengan variabel error $\delta 9$.

3. Untuk variabel $\mathrm{SV}$

$\mathrm{SV} 1.1=\lambda_{\mathrm{x} 25} \xi 3+\delta 15$

$\mathrm{SV} 2.1=\lambda_{\mathrm{x} 26} \xi 3+\delta 16$

$\mathrm{SV} 3.1=\lambda_{\mathrm{x} 27} \xi 3+\delta 17$

$\mathrm{SV} 4.1=\lambda_{\mathrm{x} 28} \xi 3+\delta 18$

$\mathrm{SV} 4.2=\lambda_{\mathrm{x} 29} \xi 3+\delta 19$

$\mathrm{SV} 5.1=\lambda_{\mathrm{x} 30} \xi 3+\delta 20$ 
Maksud dari persamaan ini adalah SV1.1 memberikan pengaruh sebesar $\lambda_{\mathrm{x} 25}$ terhadap variabel laten SV ditambah dengan variabel error $\delta 15$.

4. Untuk variabel IU

$$
\begin{aligned}
& \mathrm{IU} 1.1=\lambda_{\mathrm{y} 11} \eta 1+\varepsilon 1 \\
& \mathrm{IU} 2.1=\lambda_{\mathrm{y} 12} \eta 1+\varepsilon 2 \\
& \mathrm{IU} 3.1=\lambda_{\mathrm{y} 13} \eta 1+\varepsilon 3
\end{aligned}
$$

Maksud dari persamaan ini adalah IU1.1 memberikan pengaruh sebesar $\lambda_{y 11}$ terhadap variabel laten IU ditambah dengan variabel error $\varepsilon 1$.

\section{Untuk variabel US}

$$
\begin{aligned}
\mathrm{US} 1.1 & =\lambda_{\mathrm{y} 14} \eta 2+\varepsilon 4 \\
\mathrm{US} 1.2 & =\lambda_{\mathrm{y} 15} \eta 2+\varepsilon 5 \\
\mathrm{US} 2.1 & =\lambda_{\mathrm{y} 16} \eta 2+\varepsilon 6 \\
\mathrm{US} 3.1 & =\lambda_{\mathrm{y} 17} \eta 2+\varepsilon 7 \\
\mathrm{US} 3.2 & =\lambda_{\mathrm{y} 18} \eta 2+\varepsilon 8
\end{aligned}
$$

Maksud dari persamaan ini adalah US1.1 memberikan pengaruh sebesar $\lambda_{\mathrm{y} 14}$ terhadap variabel laten US ditambah dengan variabel error $\varepsilon 4$.

6. Untuk variabel NB

$$
\begin{aligned}
& \mathrm{NB} 1.1=\lambda_{\mathrm{y} 19} \Pi 3+\varepsilon 9 \\
& \mathrm{NB} 2.1=\lambda_{\mathrm{y} 20} \not 3+\varepsilon 10
\end{aligned}
$$

Maksud dari persamaan ini adalah NB1.1 memberikan pengaruh sebesar $\lambda_{y 19}$ terhadap variabel laten NB ditambah dengan variabel error $\varepsilon 9$. adalah

Sedangkan untuk konversi diagram secara struktural

$$
\begin{aligned}
& \eta 1=\gamma 11 \xi 1+\gamma 12 \xi 2+\gamma 13 \xi 3+\zeta 1 \\
& \eta 2=\gamma 21 \xi 1+\gamma 22 \xi 2+\gamma 23 \xi 3+\beta 1 \eta 1+\zeta 2 \\
& \eta 3=\beta 1 \eta 1+\beta 2 \eta 2+\zeta 3
\end{aligned}
$$

$$
\begin{aligned}
& \text { Keterangan : } \\
& \eta 1=\text { Variabel IU } \\
& \eta 2=\text { Variabel US } \\
& \eta 3=\text { Variabel NB } \\
& \xi 1=\text { Variabel IQ } \\
& \xi 2=\text { Variabel SQ } \\
& \xi 3=\text { Variabel SV }
\end{aligned}
$$

\section{HASIL DAN PEMBAHASAN}

\subsection{Hasil Analisis}

Berikut merupakan hasil analis berdasarkan hasil analisis terhadap hubungan kausal variabel laten eksogen dan variabel laten endogen.

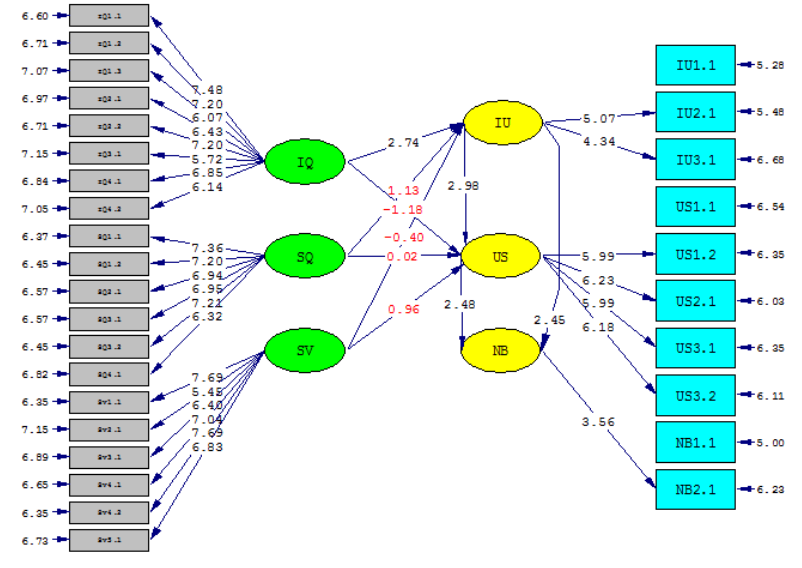

Gambar 6 T-Value

Pada Gambar 6 menunjukkan nilai $t$-value terdapat 6 variabel laten dan 9 hipotesa. Variabel laten yang berwarna hijau adalah variabel laten eksogen dan yang berwarna kuning adalah variabel laten endogen. Hipotesa ditunjukkan pada garis lurus antara variabel laten. Hipotesa $t$-value yang berwarna merah menunjukkan variabel tidak signifikan $(t$ value $\leq 1,65)$, sedangkan hipotesa $t$-value yang berwarna hitam memiliki nilai yang signifikan ( $t$-value $\geq 1,65)$.

\subsection{Hasil Hipotesa}

Berikut ini merupakan hasil dari hipotesa dan kesimpulannya :

1. Berdasarkan hasil pengujian hipotesis pada Gambar 6, meyatakan bahwa Information Quality memiliki dampak signifikan terhadap Intention to Use. Hal ini berarti bahwa semakin tinggi kegiatan Information Quality yang meliputi keakuratan informasi, ketepatan waktu, kelengkapan informasi, penyajian informasi, maka akan meningkatkan keinginan untuk menggunakan aplikasi sistem informasi penerimaan online.

2. Berdasarkan hasil pengujian hipotesis pada Gambar 6, meyatakan bahwa System Quality tidak memiliki dampak yang signifikan terhadap Intention to Use tetapi hanya memiliki dampak yang kecil dengan nilai sebesar 1.13. Hal ini berarti bahwa kegiatan System Quality yang meliputi kemudahan penggunaan, kemudahan akses, kecepatan akses dan keamanan memiliki pengaruh yang kecil terhadap keinginan karyawan untuk menggunakan aplikasi sistem informasi penerimaan online.

3. Berdasarkan hasil pengujian hipotesis pada Gambar 6, meyatakan bahwa Service Quality tidak memiliki dampak signifikan terhadap Intention to Use tetapi hanya memiliki dampak yang kecil dan berlawan dikarenakan nilai t-value bernilai negatif dengan nilai sebesar $-0,4$. Hal ini berarti bahwa kegiatan Service Quality yang meliputi tampilan, kehandalan, daya tanggap, jaminan dan kepedulian memiliki pengaruh yang kecil dan berlawanan dengan keinginan karyawan untuk menggunakan aplikasi sistem informasi penerimaan online. Dengan kata lain semakin tinggi kualitas layanan yang diberikan, maka karyawan tidak terlalu menginginkan menggunakan sistem tersebut. 
4. Berdasarkan hasil pengujian hipotesis pada Gambar 6, meyatakan bahwa Information Quality tidak memiliki dampak signifikan terhadap User Satisfaction tetapi hanya memiliki dampak yang kecil dan berlawan dikarenakan nilai $t$-value bernilai negatif dengan nilai sebesar -1.18. Hal ini berarti bahwa kegiatan Information Quality yang meliputi keakuratan informasi, ketepatan waktu, kelengkapan informasi dan penyajian informasi memiliki pengaruh yang kecil dan berlawanan terhadap kepuasan karyawan dalam menggunakan aplikasi sistem informasi penerimaan online. Dengan kata lain semakin tinggi kualitas informasi yang diberikan, maka karyawan tidak terlalu puas dalam menggunakan sistem tersebut.

5. Berdasarkan hasil pengujian hipotesis pada Gambar 6, meyatakan bahwa System Quality tidak memiliki dampak signifikan terhadap User Satisfaction tetapi hanya memiliki dampak yang kecil dengan nilai sebesar 0.02. Hal ini berarti bahwa kegiatan System Quality yang meliputi kemudahan penggunaan, kemudahan akses, kecepatan akses dan keamanan memiliki pengaruh yang kecil terhadap kepuasan karyawan dalam menggunakan aplikasi sistem informasi penerimaan online.

6. Berdasarkan hasil pengujian hipotesis pada Gambar 6, meyatakan bahwa Service Quality tidak memiliki dampak signifikan terhadap User Satisfaction tetapi hanya memiliki dampak yang kecil dengan nilai sebesar 0.96. Hal ini berarti bahwa kegiatan Service Quality yang meliputi tampilan, kehandalan, daya tanggap, jaminan dan kepedulian memiliki pengaruh yang kecil terhadap kepuasan karyawan dalam menggunakan aplikasi sistem informasi penerimaan online.

7. Berdasarkan hasil pengujian hipotesis pada Gambar 6, meyatakan bahwa Intention to Use memiliki dampak signifikan terhadap User Satisfaction. Hal ini berarti bahwa semakin tinggi kegiatan Intention to Use yang meliputi persepsi kemudahan penggunaan, persepsi penggunaan, etika, maka akan meningkatkan kepuasan karyawan dalam menggunakan aplikasi sistem informasi penerimaan online.

8. Berdasarkan hasil pengujian hipotesis pada Gambar 6, meyatakan bahwa Intention to Use memiliki dampak signifikan terhadap Net Benefit. Hal ini berarti bahwa semakin tinggi kegiatan Intention to Use yang meliputi persepsi kemudahan penggunaan, persepsi penggunaan, etika, maka akan meningkatkan keuntungan dalam menggunakan aplikasi sistem informasi penerimaan online.

9. Berdasarkan hasil pengujian hipotesis pada Gambar 6, meyatakan bahwa User Satisfaction memiliki dampak signifikan terhadap Net Benefit. Hal ini berarti bahwa semakin tinggi kegiatan User Satisfaction yang meliputi keefetifan, efisiensi, kepuasan, maka akan meningkatkan keuntungan dalam menggunakan aplikasi sistem informasi penerimaan online.
Tabel 1 Hasil Analisis

\begin{tabular}{|c|c|c|c|c|}
\hline \multicolumn{5}{|c|}{ HASIl ANALISIS } \\
\hline EKSOGEN & ENDOGEN & T-Tabel & t-Vailue & KETERANGAN \\
\hline$\overline{\mathrm{IQ}}$ & $\overline{I U}$ & 1,65 & 2,74 & SIGNIFIRAN \\
\hline$\overline{S Q}$ & $\overline{\mathrm{IU}}$ & 1,65 & 1,13 & $\begin{array}{c}\text { IIDAR } \\
\text { SIGNIFIRAN }\end{array}$ \\
\hline SV & $\overline{\mathrm{IU}}$ & 1,65 & $-0,4$ & $\begin{array}{c}\text { IIDAK } \\
\text { SIGNIFIRAN }\end{array}$ \\
\hline IQ & US & 1,65 & $-1,18$ & $\begin{array}{l}\text { IIDAR } \\
\text { SIGNIFIKAN }\end{array}$ \\
\hline SQ & US & 1,65 & 0,02 & $\begin{array}{c}\text { TIDAR } \\
\text { SIGNIFIKAN }\end{array}$ \\
\hline SV & US & 1,65 & 0,96 & $\begin{array}{l}\text { TIDAR } \\
\text { SIGNIFIKAN }\end{array}$ \\
\hline$\overline{\Gamma U}$ & $\overline{U S}$ & 1,65 & 2,98 & SIGNIFIKAN \\
\hline IU & NB & 1,65 & 2,45 & SIGNIFIKAN \\
\hline US & $\overline{\mathrm{NB}}$ & 1,65 & 2,48 & SIGNIFIKAN \\
\hline
\end{tabular}

\subsection{Hasil Eksperimen}

Berdasarkan pada hasil penelitian yang telah dilakukan, maka didapatkan kesimpulan yaitu:

1. Dari hasil uji validitas dengan menggunakan nilai loading factor terhadap yang dapat dilihat pada path diagram nilai loading factor eksogen dan endogen lebih dari 0,5 sehingga bernilai valid.

2. Dari hasil uji reliabilitas dengan menggunakan penghitungan manual menunjukkan bahwa keseluruhan nilai $\mathrm{CR}$ lebih dari o,6 sehingga didapatkan hasil yang reliabel.

3. Berdasarkan hasil uji hipotesis terdapat beberapa hipotesis yang signifikan seperti Information Quality terhadap Intention to Use, Intention to Use terhadap User Satisfaction, Intention to Use terhadap Net Benefit, User Satisfaction terhadap Net Benefit.

4. Information Quality berpengaruh signifikan terhadap Intention to Use menunjukkan bahwa semakin baik kualitas informasi Sistem Informasi Penerimaan Online maka semakin besar keinginan user/karyawan untuk menggunakan sistem tersebut.

5. Intention to Use berpengaruh signifikan terhadap User Satisfaction menunjukkan bahwa semakin tinggi keinginan untuk menggunakan Sistem Informasi Penerimaan Online maka semakin user/karyawan merasa puas dalam menggunakan sistem tersebut.

6. Intention to Use berpengaruh signifikan terhadap Net Benefit menunjukkan bahwa semakin tinggi keinginan user/karyawan menggunakan Sistem Informasi Penerimaan Online maka semakin besar juga keuntungan dalam menggunakan sistem tersebut.

7. User Satisfaction berpengaruh signifikan terhadap Net Benefit menunjukkan bahwa semakin puasnya pengguna dalam menggunakan Sistem Informasi Penerimaan Online maka semakin besar keuntungan yang didapatkan dalam menggunakan sistem tersebut. 
8. Dari sembilan hipotesis yang ada, hanya empat hipotesis saja yang memiliki pengaruh secara signifikan, dan untuk lima hipotesis lainnya tidak memiliki pengaruh antara eksogen dan endogennya.

\section{KESIMPULAN DAN SARAN}

\subsection{Kesimpulan}

Dari penelitian ini didapatkan kesimpulan:

1. Metode ISSM dapat digunakan untuk melakukan evaluasi terhadap kesuksesan aplikasi Sistem Informasi Penerimaan Online.

2. Faktor yang mempengaruhi terhadap kesuksesan terhadap sistem informasi penerimaan online adalah faktor Information Quality terhadap Intention Use, Intention to Use terhadap User Satisfaction, Intention to Use terhadap Net Benefit dan yang terakhir adalah adalah pengaruh terhadap faktor User Satisfaction terhadap Net Benefit.

\subsection{Saran}

Dari pelaksanaan penelitian tugas akhir ini dapat diberikan saran untuk penelitian selanjutnya antara lain:

1. Penelitian selanjutnya menggunakan studi kasus terhadap Otoritas Jasa Keuangan dengan menggunakan sistem atau aplikasi lainnya.

2. Penelitian selanjutnya menyebarkan kuisioner terhadap internal Otoritas Jasa Keuangan si seluruh Indonesia atau menggunakan obyek $e$ goverment lainnya.

3. Penelitian selanjutnya menggunakan model evaluasi lain misalkan ISO 9000,ID -TAM, dan Servqual.

4. Penelitian selanjutnya menggunakan tools seperti AMOS, GESCA atau SmartPLS.

\section{DAFTAR PUSTAKA}

[1] Otoritas Jasa Keuangan. (n.d.). tugas dan fungsi. Retrieved October 1, 2015, from Otoritas Jasa Keuangan web site: http://www.ojk.go.id/tugas-dan-fungsi.

[2] Otoritas Jasa Keuangan. (n.d.). Sistem Informasi Penerimaan Online. Retrieved October 1, 2015, from Otoritas Jasa Keuangan Web Site: http://www.ojk.go.id/App/sipo.

[3] deLone, W. H., \& McLEAN, E. R. (2003). The DeLone and McLean Model of Information Systems Success: A Ten-Year Update. Journal of Management Information Systems / Spring.

[4] Sritharan, V. (2013). SERVICE QUALITY: AND EMPIRICAL ANALYSIS OF NATIONAL SAVING BANKS IN NORTHERN PROVINCE IN SRI LANKA. International Journal of Advanced Research in Management and Social Sciences.

[5] Bailey, J., \& Pearson, S. (1983). Development of a tool for measurement and analyzing computer user satisfaction. Management Science, 530 - 575.

[6] James Wallace, Nelarine E. Cornelius Zahid Hussein, "The
Use and Impactof Human Resource Information Systems on Human Resource Management Profesionals," Information and Management, pp. 74-89, 2007.

[7] Preacher, K. J. (2006). Testing Complex Correlational Hypotheses With Structural Equation Models. STRUCTURAL EQUATION MODELING, 13(4) , 520543.

[8] A. Ferdinand, Structural Equation Modelling dalam Penelitian Manajemen, Semarang: Badan Penerbit Diponegoro, 2002.

[9] Fuad dan Ghozali, "Structural Equation Modeling: Teori, Konsep, dan Aplikasi," 2005.

[10] S. Santoso, Structural Equation Modeling (SEM), Jakarta: PT. Alex Media Komputindo, 2011. 